\title{
Effect of Learning Strategy and Cognitive Styles on Students' Learning Outcomes of Civic Education and Social Skills
}

\author{
Jamaludin \\ Lecturers of Social Science Education \\ Universitas Tadulako \\ Central Sulawesi, Indonesia \\ anak_dondo@yahoo.com \\ Kaharuddin Nawing \\ Lecturers of Social Science Education \\ Universitas Tadulako \\ Central Sulawesi, Indonesia \\ karnam_2010@yahoo.com
}

\author{
Imran \\ sahaliaimran@gmail.com \\ Lecturers of Social Science Education \\ Universitas Tadulako \\ Central Sulawesi, Indonesia
}

\begin{abstract}
The core of civic education both in concept and implementation is the students' change in relation to learning outcome which covers cognitive, effective, and psychomotor domains. This can be reached when learning is organized, carried out, and managed effectively by teachers. This study describes the relationship between learning strategy of two stays two stray and direct instruction which is connected with cognitive styles of field independent and field dependent to the students' comprehension and social skills. This study used a quasi-factorial experimental design of $2 \times 2$. The subject was Grade XI students of the State Senior High Schools in Palu. The subjects were divided into two groups consisting of the students taught using cooperative learning strategy of two stays two stray and the students taught using direct instruction. The study shows that 1) there is a significant difference of comprehension on the civic education of the students taught using cooperative learning strategy of two stay two stray and those taught using direct instruction, 2) there is no significant difference in comprehension between the students with cognitive style of field independent and the ones with cognitive style of field dependent, 3) there is no interaction between the learning strategy and the students' cognitive styles.
\end{abstract}

Keywords-Learning Strategy, Cognitive Styles, Learning Outcomes, Civic Education, and Social Skills

\section{INTRODUCTION}

Civic education plays a strategic role in shaping students in order to develop their knowledge and skill for daily life. They are able to think critically, be responsible, develop positively, and contribute to democratic attitudes. Civic education at schools is a subject provided to incorporate three basic aspects: civic knowledge, civic skill, and civic disposition [1]. The aspects are extremely important and simultaneously integrated into any part of the learning process in order to develop the students. This makes civic education not only stressing academic achievement but also shaping the students' civic attitudes and values. Ref. [2] argues that education has two main roles, that is, to enable the students to academically developing and to be a good person.

In relation to this, good conduct is conceptualized as students have moral objective values which foster human dignity and promote individual and social conducts in real life. Ref. [3] points out that learning at schools needs to promote and develop good attitudes such as empathy, generous, social, and helpful in the school community.

Promoting positive attitudes in the real life of school requires attention from both teachers and staff and those values for students should be continuously incorporated into any activity of learning. There is a number of reasons for this purpose [4]. First, there has been a negative effect on the social relationship on young generation to be individualistic which tends to ignore care to other people. Second, many students tend to discourage social sensitivity and empathy to others. Third, students often see and feel social conflicts in the society, particularly those occurring at schools.

Such negative values toward the students' attitudes are also influenced by the school teacher's attitudes which indicate low responsibility in doing their professional jobs. Ref. [5] maintains that school teachers tend to do their classroom teaching as routinely and regular job. Now teachers are challenged with the students who tend to show low respects and anarchic conducts to others such as fighting, insulting, and committing physical 
violence. Ref. [6] found that the students' academic achievement on civic education is inconsistent with their attitudes.

By considering all the problems above, we reflect that conventional learning strategy needs to be improved and developed in order to promote and foster the students' involvement and creativity. The learning strategy which emphasizes verbalism seems ineffective in promoting the students' creativity.

Therefore, teachers of civic education are demanded to provide learning strategy which facilitates meaningful learning. This could address the curriculum goals the students' involvement in learning. The students are likely to feel satisfied when the classroom learning and teaching are set to be dynamic without much control of the teachers. By providing an effective learning strategy, the students are likely to reach the stated learning outcomes. According to [7], there are three components that should be taken into consideration for successful teaching: a strategy for organizing, delivery, and learning management.

This study attempts to describe the relationship between cooperative learning of two stays two stray type and direct instruction which is connected with cognitive styles of field independent and field dependent to the students' comprehension and social skills.

\section{RESEARCH METHOD}

This study used a quasi-experimental design with factorial design 2 x 2 by employing non-equivalent control group design.Factorial design can determine the main effect of the variables on the students' comprehension and social skills, the effect of field-independent cognitive style and field-dependent cognitive style, and the interaction effect of the independent variable and moderating variable as depicted below.

TABLE I FACTORIAL EXPERIMENTAL DESIGN 2X2.

\begin{tabular}{|c|c|c|}
\hline \multirow{2}{*}{ Cognitive Styles } & \multicolumn{2}{|c|}{ Learning Strategy } \\
\hline & Two Stay Two Stray & Direct instruction \\
\hline Field Independent & $Y_{1.1 .1,}, Y_{1.1 .2,} Y_{1.1 .3,} Y_{1.1 . n . .}$ & $Y_{1.2 .1}, Y_{1.2 .2}, Y_{1.2 .3}, Y_{1.2 . \mathrm{n}}$ \\
\hline Field Dependent & $Y_{2.1 .1,}, Y_{2.1 .2,} Y_{2.1 .3,}, Y_{2.1 . n .}$ & $\mathrm{Y}_{2.2 .1,}, \mathrm{Y}_{2.2 .2,}, \mathrm{Y}_{2.2 .3,}, \mathrm{Y}_{\text {2.2.2n.. }}$ \\
\hline
\end{tabular}

The subject of this study was Grade XI students of SMA Negeri 1 Palu, SMA Negeri 2 Palu, and SMA Negeri 5 Palu. The total number of the students was 183 . The subject was selected based on the groups or grades used in each school. There are some instruments used in this study. First, Test of Cognitive Style, that is, Group Embedded Figures Test (GEFT) used to identify the students' cognitive style Witkin in [8]. This test is used to measure the students' ability in finding a hidden simple form of a complex pattern. The test consisted of 18 pictures that need to be finished in specific time. A correct answer is scored 1 and wrong answer is scored 0 . The students with 0-9 scores are field-dependent cognitive style and those with 10-18 scores are field-dependent cognitive style. Second, Comprehension Test in multiple-choice format was administered to measure the students' comprehension after the treatment. The test consisted of 34 items containing content standard 2006, standard competence, and basic competence in civic education for Grade XI [9], and Third, Likert Scale [10] Questionnaire was used to find out the student's perceptions, attitudes, opinions relating to the use of learning strategy.The instrument of social skills covered 4 aspects: 1) Empathy, 2) Generosity, 3) Teamwork, and 4) Giving help. Each aspect consisted of 7 statements. The total number was 28 statements with a range of scale: (1) Strongly Disagree, (2) Disagree, (3) Neither Agree nor Disagree (neutral), (4) Agree, and (5) Strongly Agree. The students' score can range from 28 to 140.

Furthermore, the data of the students' comprehension scores and social skills were analyzed by using SPSS Statistics 17.0 for Windows Program. Before the analysis, pre-requisite statistical testing which includes normality and homogeneity testing was conducted. In finding out the difference among students, nonparametric analysis was used by employing Two-sample Kolmogorov-Smirnov Test and Kruskal-Wallis Test [10]. This study also used hypothesis testing of Manova. If the value of probability $<\alpha$, Ho is refused and if the value of probability $\geq \alpha$, Ho is accepted $(\alpha=0,05)$.

\section{RESULTS AND DISCUSSION}

Based on the hypothesis testing, it is found that there is a significant difference between the students who learned through cooperative learning with two stay two stray and those who learn through direct instruction. The students' learning outcome of civic education taught with cooperative learning with two stay two stray is higher than those with direct instruction. This result shows that cooperative learning with two stay two stray is effective in enhancing the quality of student learning in civic education as shown in the following table.

TABLE II. RESUltS OF LEARNING COMPREHENSION AND SOCIAL SKILLS

\begin{tabular}{|l|c|c|c|c|}
\hline \multirow{2}{*}{\begin{tabular}{c}
\multirow{2}{*}{$\begin{array}{c}\text { Cognitive } \\
\text { Styles }\end{array}$} \\
\cline { 2 - 5 }
\end{tabular}} & \multicolumn{4}{|c|}{ Tearning Strategy } \\
\cline { 2 - 5 } & Comprehension & Social Skills & Comprehension & $\begin{array}{c}\text { Social } \\
\text { Skills }\end{array}$ \\
\hline $\begin{array}{l}\text { Field } \\
\text { Independent }\end{array}$ & 68.64 & 82.34 & 43.34 & 48.25 \\
\hline $\begin{array}{l}\text { Field } \\
\text { dependent }\end{array}$ & 67.63 & 83.07 & 41.43 & 48.15 \\
\hline Total & 68.12 & 82.71 & 42.09 & 48.18 \\
\hline
\end{tabular}

Ref. [11] maintains that learning strategy has an important role in attracting and encouraging students for the lesson. The quality of student learning is optimal and they can achieve the instructional objective. One indicator to see that learning is effective is that the students appreciate and show their enthusiasm for learning. 
This research indicates that learning which promotes the students' creativity and innovation needs to provide equal participation. On the other hand, learning which discourages creativity and innovation has a negative impact on the students.In fact, rote-learning which puts the emphasis on memorization can discourage the students to think critically and creatively. As a result, the students' learning is not meaningful. Cooperative learning strategy of two stay two stray promotes students to share with their peers and this also could develop the students' social skills.

In relation to this result, [12], [13], [14] and Research Review by [15] confirm that using cooperative learning is effective than using expository instruction. Cooperative learning strategy could result in higher achievement on civic education compared with direct instruction. Importantly, $72 \%$ students achieved a higher result. This result could take place because the learning enables the students to support one another to get success for the group. Ref. [16] maintains that cooperative learning can be used to develop the students' academic achievement and social skills.

Cognitive style is also addressed in this paper. In Table III, we can see that the experimental group of 44 students with fieldindependent cognitive style, the control group of 32 students with field-independent cognitive style, the experimental group of 46 fields dependent cognitive style, and the control group of 61 students with field-dependent cognitive style.

TABLE III. Students’ Cognitive STYLES

\begin{tabular}{|c|c|c|c|c|c|c|}
\hline \multirow{2}{*}{ No } & \multirow{2}{*}{ Schools } & \multicolumn{4}{|c|}{ Learning Strategy } & \multirow{2}{*}{$\begin{array}{c}\text { Number } \\
\text { of } \\
\end{array}$} \\
\cline { 3 - 6 } & & $\begin{array}{c}\text { Stray } \\
\text { Students }\end{array}$ \\
\cline { 3 - 6 } & & $\boldsymbol{F I}$ & $\boldsymbol{F D}$ & $\boldsymbol{F I}$ & $\boldsymbol{F D}$ & \\
\hline $\mathbf{1}$ & SMA Negeri 1 & 16 & 16 & 12 & 20 & 64 \\
\hline $\mathbf{2}$ & SMA Negeri 2 & 16 & 14 & 10 & 20 & 60 \\
\hline $\mathbf{3}$ & SMA Negeri 5 & 12 & 16 & 10 & 21 & 59 \\
\hline & Total & 44 & 46 & 32 & 61 & 183 \\
\hline
\end{tabular}

The result is obtained after the students took Cognitive Style Test. Based on the grouping of the students' cognitive styles, we can see the average of learning outcomes of comprehension and social skills as shown in Table IV below.

TABLE IV. THE RESUlt of LEARNING COMPREHENSION AND SOCIAL SKILlS

\begin{tabular}{|l|c|c|}
\hline \multicolumn{1}{|c|}{ Cognitive Styles } & Comprehension & Social Skills \\
\hline Field Independent & 57,98 & 67,99 \\
\hline Field Dependent & 52,70 & 63,16 \\
\hline Total & 54,90 & 65,16 \\
\hline
\end{tabular}

Although the cognitive style is one of the variables that teachers need to take into account when preparing and designing instructional process, it indicates that there is no difference on comprehension and social skills between the students with fieldindependent cognitive style and those with field-dependent cognitive style. It means that the students' comprehension on civic education and social skills is not influenced by their cognitive styles. This is due to the fact that the characteristics of the lesson and the instructional materials on civic education seem not to bring about the students' different learning results. Similar studies were conducted by [17], [18], [19], \& [20]. They found that there was no difference in learning outcome between the students with field-independent cognitive style and with fielddependent cognitive style.

The difference of learning comprehension and social skills between the students taught through learning strategy of two stay two stray and direct instruction; and there is no difference of learning comprehension and social skills between the students with field-independent cognitive style and those with fielddependent cognitive style suggests there is no interaction between learning strategy and the students' cognitive styles. This can be seen in the following figure.

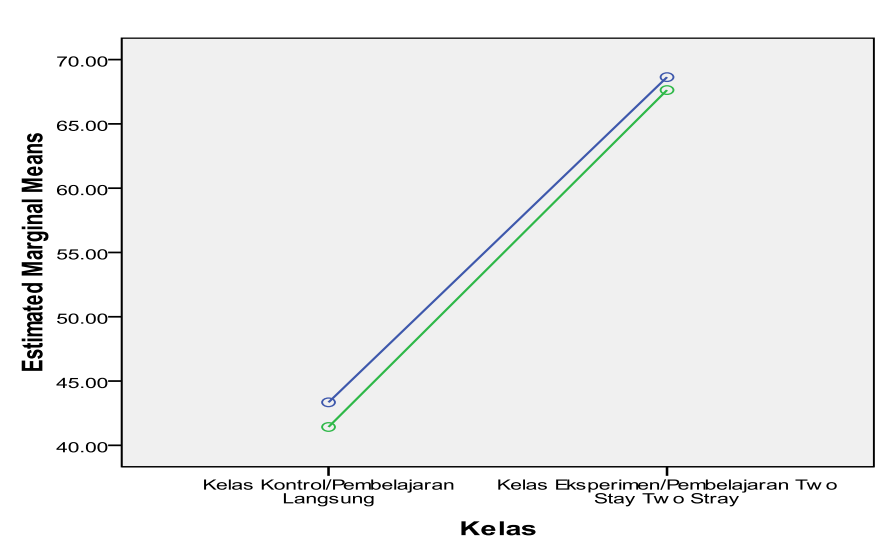

Fig.1. Interaction between Learning Strategy and Cognitive Style

The figure above shows that the absence of cutting line both ordinal and disordinal indicates that there is no interaction between the students' learning strategy and their cognitive styles. This result describes the main effect caused by the independent variable without taking into account the other variable. This means that there is no interaction between the independent variable and the dependent variable. In other words, learning strategy can independently shape the students' comprehension and their social skills.

\section{CONCLUSIONS}

Using cooperative learning strategy of two stay two stray type has a significant effect on the students' comprehension and social skills on civic education. The difference of the students' cognitive style does not significantly affect the students' comprehension and social skills. This indicates that the learning strategy and the students' cognitive style work independently in the learning process so that there is no interaction between the learning 
strategy and the students' cognitive style in comprehension and social skills. It is suggested that teachers of civic education should change their paradigm from teaching-oriented to learningoriented. Using cooperative learning strategy of two stay two stray is alternative to help students in understanding concepts of politic culture.

\section{REFERENCES}

[1] M. S. Branson, "The Role of Civic Education: An Education Policy Task Force Position Paper With Policy Recommendations," Washington DC, 1998.

[2] T. Lickona, Educating For Character:Mendidik untuk Membentuk Karakter. terjemahan oleh Juma Abdu Wamaugo. Jakarta: PT Bumi Aksara, 2013.

[3] Janice J. Beaty, Prosocial Guidance for the Preschool Child Published. Prentice Hall Career \& Technology, 2008.

[4] B. Maftuh, "Memperkuat Peran IPS dalam Membelarkan Keterampilan Sosial dan Resulusi Konflik. Pidato Pengukuhan Jabatan Guru Besar dalam bidang Pendidikan Ilmu Pengetahuan sosial,” Jakarta, 2010.

[5] Cholisin, Training Of TOT, Nasional Guru Mata Pelajaran Pendidikan Kewarganegaraan. Jakarta: Dirjen Pendidikan Lanjutan Pertama. Dirjen Dikdasmen Depdiknas., 2005.

[6] Handoko, "Pengembangan Model Pendidikan Moral Consideration Model dengan Scaffolding untuk membentuk Karakter Kematangan Moral siswa Melalui Pembelajaran PKN," Samarinda, 2011.

[7] I. N. S. Degeng, Ilmu Pengajaran Taksonomi Variabel. Jakarta: Departemen Pendidikan dan Kebudayaan Direktorat Jenderal Pendidikan Tinggi, 1989.

[8] I. N. S. Degeng, "Pengaruh Strategi Penataan Isi Modul, Gaya Kognitif dan Strategi Belajar mahasiswa terhadap Perolehan Belajar," J. Teknol. Pembelajaran Teor. dan Penelit., vol. Tahun 4 No, 1996.

[9] BSNP, Panduan Penyusunan Kurikulum Tingkat Satuan Pendidikan Jenjang Pendidikan Dasar dan Menengah. Jakarta, 1998.
[10] Sugiyono, Metode Penelitian Pendidikan (Pendekatan Kuantitatif, Kualitatif dan RD). Bandung: Alfabeta, 2007.

[11] I. N. S. Degeng and M. Pali, Model Pembelajaran Berorientasi Pengembangan Kecerdasan emosional di Sekolah Dasar. Malang: Kementerian Riset dan Teknologi RI. Lembaga Ilmu Pengetahuan Indonesia., 2002.

[12] T. G. Ratumanan, "Pengaruh Model Pembelajaran dan Gaya Kognitif terhadap Hasil Belajar Matematika," J. Pendidik. Dasar, vol. 5 (1), pp. 35 38, 2003.

[13] E. Solihatin, "Pengaruh Strategi Pembelajaran dan Gaya Kognitif terhadap Hasil Belajar Pendidikan Kewarganegaraan," J. Ilm. Mimb. Demokrasi.Jurusan Ilmu Sos. Polit. Fak. Ilmu Sos., vol. 5 (3), pp. 37-40, 2011.

[14] R. I. Arends, Learning To Teach. Terjemahan oleh Helly Prayitno Soejipto \& Sri Mulyantini Soetjipto. Yogyakarta: Pustaka Pelajar, 2008.

[15] R. E. Slavin, Cooperative Learning, Teori,Riset dan Praktek. terjemahan oleh Narulita Yusron. Bandung: Nusa Media, 2005.

[16] A. Lie, Cooperative Learning, Mempraktikkan Cooperative Learning di Ruang-Rruang Kelas. Jakarta: Gramedia, 2004.

[17] Rufi, "Pengaruh Strategi Pembelajaran dan Gaya Kognitif terhadap Perolehan Belajar Prosedur Statistika," J. Wahana Univ. PGRI Adi Buana, vol. 57 (2), 2012.

[18] S. Ates and E. Cataloglu, "The Effects of Students' Cognitive Style on Conceptual Understanding and Problem-Solving Skills In Introductory Mechanics,” J. Res. Sci. Technol. Educ., vol. 25, no. 2, pp. 167-178, 2007.

[19] Sugiarso, "Pengaruh Penggunaan Strategi Awal Pembelajaran Advance Organizer dan Epitome terhadap Hasil Belajar Mahasiswa yang Bergaya Kognitif Berbeda," Universitas Negeri Malang, 2000.

[20] Hasanah, "Pengaruh strategi pembelajaran (concept map dan word journal) dan Gaya Kognitif Mahasiswa terhadap Hasil Belajar Pemahaman Konsep Mata Kuliah Ilmu Kalam di Jurusan Tarbiyah STAIN Jember," Universitas Negeri Malang, 2006. 